\title{
IDENTIFIKASI BAKTERI Escherichia coli SUSU KEDELAI MURNI DI PASAR JODOH KOTA BATAM
}

\section{Identification Of Escherichia coli In Pure Soy Milk At The Market Of Jodoh Batam City}

\section{Sri Hainil ${ }^{*}$}

Trie Yuni Elfasyari ${ }^{2}$

Rofina Intan Sulitya ${ }^{3}$

*,2,3Institut Kesehatan Mitra Bunda, Batam, Kepulauan Riau, Indonesia

*email: trieelfasyari@gmail.com

\begin{abstract}
Abstrak
Susu kedelai murni merupakan minuman bergizi tinggi, secara umum susu kedelai murni memiliki kandungan sangat baik untuk tubuh, berupa protein, kandungan zat besi, fosfor, karbohidrat, lemak, provitamin A dan vitamin B. Namun dalam proses pengolahan susu kedelai murni yang kurang baik dapat menyebabkan susu kedelai murni mengandung atau tercemar mikroorganisme. salah satu mikroorganisme yang dapat ditemukan dalam minuman atau air adalah bakteri Coliform. Contoh bakteri Coliform adalah Escherichia coli. Escherichia coli merupakan bakteri yang hidup didalam usus manusia, bakteri ini hidup sebagai flora normal atau dapat disebut kumpulan mikroorganisme, yang secara alami terdapat pada tubuh manusia normal dan sehat. Tujuan penelitian untuk mengetahui ada tidaknya bakteri Escherichia coli pada susu kedelai murni yang dijual di Pasar Jodoh Kota Batam.Dalam penelitian ini digunakan metode (Most Probable Number) MPN. Hasil penelitian pada 10 sampel susu kedelai murni $A, B, C, D, E, F, G, H, I, J$ dan 2 sampel susu kedelai bermerek $K$, dan $L$ terdapat bakteri coliform dan terdapat 6 bakteri Escherichia coli pada sampel susu kedelai murni A, B, C, D, G, dan pada sampel susu kedelai bermerek K. Dari hasil pemeriksaan 12 sampel susu kedelai tidak memenuhi syarat Standar Nasional Indonesia (SNI OI - 3830 - 1995).
\end{abstract}

\section{Kata Kunci: \\ Esherichia coli \\ Koliform \\ Susu kedelai \\ Keywords: \\ Escherichia coli \\ Coliform \\ Soymilk}

\begin{abstract}
Pure soy milk is a highly nutritious drink, in general, pure soy milk contains very good content for the body, in the form of protein, iron, phosphorus, carbohydrates, fat, provitamin A and B vitamins. causing pure soy milk to contain or be contaminated with microorganisms. one of the microorganisms that can be found in drinks or water is the Coliform bacteria. An example of Coliform bacteria is Escherichia coli. Escherichia coli is a bacterium that lives in the human intestine, these bacteria live as normal flora or can be called a collection of microorganisms, which are naturally present in normal and healthy human bodies. The research objective was to determine the presence or absence of Escherichia coli in pure soy milk sold in Jodoh Market, Batam City. This study uses the Most Probable Number (MPN) method. The results of the study on 10 samples of pure soy milk $A, B, C, D, E, F, G, H, I, J$ and 2 samples of soy milk branded $K$, and $L$ contained coliform bacteria and there were 6 Escherichia coli bacteria in soy milk samples. pure $A, B, C, D, G$, and on samples of soy milk branded $K$. The results of the examination of 12 samples of soy milk were found not to meet the requirements of the Indonesian National Standard (INS OI - 3830 - 1995).
\end{abstract} Palangkaraya. This is Open Access article under the CC-BY-SA License (http://creativecommons.org/licenses/by-sa/4.0/). DOI: https://doi.org//0.33084/jsm.vxix.xxx.

\section{PENDAHULUAN}

Susu kedelai murni merupakan minuman hasil ekstraksi kedelai. Minuman nabati ini sering digunakan sebagai pengganti susu sapi karena dapat dikonsumsi oleh individu yang alergi laktosa (intoleransi laktosa), dan bagi mereka yang alergi susu sapi. Secara umum susu kedelai murni mengandung kandungan yang sangat baik untuk tubuh, berupa protein, zat besi, fosfor, karbohidrat, lemak, vitamin provitamin A dan B (Habullah \& Kojong, 2015).

Pengolahan susu kedelai murni yang buruk dapat menyebabkan susu kedelai murni mengandung atau tercemar mikroorganisme, hal ini terjadi karena kurang higienis dan tidak memenuhi standar sanitasi. Salah satu mikroorganisme yang dapat ditemukan pada minuman atau air adalah bakteri Coliform. Salah satu contoh 
bakteri Coliform adalah Escherichia coli (Sunarti, 2017; Jiwintarum et al., 2017).

Escherichia coli merupakan bakteri yang hidup di usus manusia, bakteri ini hidup sebagai flora normal atau bisa disebut kumpulan mikroorganisme, yang secara alami terdapat pada tubuh manusia yang normal dan sehat. Infeksi yang dapat terjadi adalah sakit perut ringan sampai berat, seringkali berupa diare, kram perut, muntah, dan demam (Sinaga, 2017; Elfidasari, 20II).

Sebagian besar susu kedelai yang dijual di toko-toko di Desa Sumobito, Jombang, positif mengandung bakteri Escherichia coli, sehingga tidak layak untuk dikonsumsi (Alfiyah et al., 2018). Empat dari sepuluh sampel susu kedelai yang diproduksi di usaha kecil dan dipasarkan di Kota Medan terbukti mengandung bakteri Escherichia coli sebanyak 50 hingga 120 per $100 \mathrm{ml}$ sampel (Sanjaya \& Apriliana, 20I3).

Sesuai dengan Standar Nasional Indonesia (SNI) No.06.8-7388-2009 persyaratan pencemaran mikroba pada produk sari kedelai, yang mengandung total plat nomor bakteri maksimum 5x104 koloni / mL, nilai MPN bakteri koliform <3 / $\mathrm{mL}$ Salmonella sp harus negatif / $25 \mathrm{~mL}$, Staphylococcus aureus Ix|02 koloni / $\mathrm{mL}$, Bacillus cereus $\mathrm{I} \times 103$ koloni $/ \mathrm{mL}$ dan $5 \times 10 \mid$ koloni jamur / mL.

Susu kedelai murni yang beredar di pasaran di kota Batam masih banyak yang belum mengidentifikasi apakah produk tersebut layak untuk dikonsumsi. Berdasarkan latar belakang tersebut maka perlu dilakukan penelitian untuk mengidentifikasi bakteri Escherichia coli pada susu kedelai yang dijual di Pasar Jodoh Kota Batam.

\section{METODOLOGI}

\section{Alat}

Alat yang digunakan dalam penelitian ini yaitu : labu Erlenmeyer, Hot plate, magnetic stirrer, pipet ukur, tabung reaksi, rak tabung reaksi, tabung durham, kapas steril, alumunium foil, Autoclave, cawan petri, label, incubator, ose jarum, ose bulat, batang pengaduk, neraca digital, bunsen, objek glass, Laminar Air Flow.

\section{Bahan}

Bahan-bahan yang digunakan antara lain : sampel Susu Kedelai Murni, Media Lactose Broth (LB), Media Briliant Green Lactose Broth (BGLB), Media Eosin Methylene Blue (EMBA), Aquadest.

\section{Metode}

\section{Pengambilan Sampel}

Sampel yang digunakan dalam penelitian ini yaitu Susu Kedelai Murni yang dijual dipasar Jodoh Kota Batam, Pengambilan sampel dilakukan secara Non Probalibility Sampling dengan Metode Accidental Sampling yaitu pengambilan sampel yang kebetulan ada atau tersedia.

\section{Pembuatan Media Lactosa Broth (LB)}

Siapkan bahan dan alat yang akan digunakan setelah itu timbang 6,5 gram serbuk Lactose Broth (LB), serbuk Lactose Broth yang telah ditimbang di masukkan ke dalam erlenmeyer. tambahkan $500 \mathrm{ml}$ aquadest lalu letakkan di atas magneter stirre agar bahan tercampur rata, lalu larutan yang telah homogen dipanaskan menggunakan kompor listrik sampai mendidih,setelah mendidih diamkan sampai dingin, setelah dingin siapkan tabung reaksi yang telah dimasukkan tabung durham terlebih dahulu lalu bagi masing - masing larutan sebanyak $10 \mathrm{ml}$. lalu tutup kembali menggunakan kapas dan masukkan ke dalam autoklaf untuk di strilisasi selama \pm 30 menit dengan suhu $121^{\circ} \mathrm{C}$.

\section{Pembuatan Media Brillian Green Lactose Broth (BGLB)}

Siapkan alat dan bahan yang akan digunakan lalu timbang Briliant Green Lactose Broth (BGLB) sebanyak 12 gram, BGLB yang telah ditimbang di masukkan ke dalam erlenmeyer. Setelah itu tambahkan $500 \mathrm{ml}$ aquadest lalu letakkan di atas magneter stirrer agar bahan tercampur rata,lalu larutan yang telah homogen dipanaskan menggunakan kompor listrik sampai mendidih, setelah mendidih diamkan sampai dingin, setelah dingin siapkan tabung reaksi yang telah dimasukkan tabung durham terlebih dahulu lalu bagi 
Sri Hainal, Trie Yuni Elfasyari, Rofina Intan Sulistya. 2021. Identifikation Of Escherichia Coli In Pure Soy Milk At The Market Of Jodoh Batam City

masing - masing larutan sebanyak $10 \mathrm{ml}$. lalu tutup kembali menggunakan kapas dan masukkan ke dalam autoklaf untuk di strilisasi selama 30 menit dengan suhu $121^{\circ} \mathrm{C}$.

\section{Pembuatan Media Eosin Methylene Blue Agar (EMBA)}

EMBA sebanyak 9 gram dilarutkan dengan air sebanyak $300 \mathrm{ml}$ di dalam labu Erlenmeyer yang sudah terdapat magnetic stirrer kemudian dipanaskan diatas hot plate. Larutan di sterilisasi dengan Autoclave selama 30 menit pada suhu $121^{\circ} \mathrm{C}$, dituangkan kedalam cawan petri yang sudah di sterilisasikan terlebih dahulu sebanyak 15 $\mathrm{ml}$ dan didiamkan sampai memadat.

\section{Uji Praduga (Presumtive Test)}

Setelah media di sterilkan pindahkan tabung reaksi yang telah diisi media ke dalam LAF ( Laminar Air Flow) setelah itu pipet sampel ke dalam 5 tabung reaksi sebanyak $10 \mathrm{ml}$, lalu pada I tabung reaksi masukkan sampel sebanyak Iml, dan pada tabung berikutnya masukkan $0,1 \mathrm{ml}$ sampel, penelitian ini menggunakan metode MPN dengan seri 5 -I-I sehingga dibutuhkan 7 tabung pada setiap sampel. Setelah semua sampel siap masukkan ke dalam inkubasi selama 24 jam dengan suhu $37^{\circ} \mathrm{C}$ dan amati hasilnya jika terdapat gelembung maka hasilnya positif $(+)$ mengandung bekteri sehinnga harus di lakukan uji berikutnya.

\section{Uji Penegas (Confirmative Test)}

Test ini dilakukan untuk menegaskan hasil positif dari test praduga. Hasil dari uji penduga ( Presumtive Test) yang positif $(+)$ akan di lanjutkan dengan uji penegas (Confirmative Test). Sampel positif di goreskan I-3 jarum ose lalu masukkan ke dalam media BGLB, setelah itu inkubasi kembali selama 24 - 48 jam dengan suhu $37^{\circ} \mathrm{C}$ agar mendapatkan hasil yang maksimal. Hasil yang positif $(+)$ ditandai dengan adanya gas.

\section{Uji Pelengkap (Completed Test)}

Dari setiap tabung yang menunjukkan hasil positif pada uji penegasan (confirmative test), dipindahkan sebanyak Ix jarum ose dari tiap tabung yang membentuk gas kedalam cawan petri yang berisikan media EMBA.
Jarum ose digoreskan kedalam cawan petri dengan $3 x$ penggoresan. Masukkan cawan petri kedalam incubator dan dicatat hasil yang positif terdapat Escherichia coli ditandai dengan hijau metalik pada cawan petri.

\section{HASIL DAN PEMBAHASAN}

\section{Uji Praduga (Presumtive Test)}

Hasil dari uji praduga (Presumtive Test) pada media Lactose Broth (LB), sampel susu kedelai yang telah di inkubasi selama \pm 24 jam pada suhu $36^{\circ} \mathrm{C}$ didalam inkubator menujukkan bahwa 10 sampel susu kedelai murni A, B, C, D, E, F, G, H, I, J yang dijual di Pasar Jodoh Kota Batam dan 2 sampel susu kedelai bermerek K, L yang ditanam dalam media Lactosa Broth (LB), memiliki hasil positif $(+)$ karena terdapat gelembung kecil atau gas yang ada didalam tabung durham dan naik keatas permukaan tabung reaksi, serta terjadi kekeruhan di dalam media.

\section{Tabel I. Hasil Uji Praduga}

\begin{tabular}{|c|c|c|c|c|c|c|c|}
\hline \multirow{3}{*}{ Sampel } & \multicolumn{7}{|c|}{ Uji Praduga Pada Media Lactosa Broth (LB) } \\
\hline & $\begin{array}{c}\text { Seri } \\
\text { I }\end{array}$ & $\begin{array}{c}\text { Seri } \\
\text { II }\end{array}$ & $\begin{array}{c}\text { Seri } \\
\text { III }\end{array}$ & $\begin{array}{c}\text { Seri } \\
\text { IV }\end{array}$ & $\begin{array}{c}\text { Seri } \\
\vee\end{array}$ & Seri & Seri \\
\hline & \multicolumn{5}{|c|}{$5 \times 10 \mathrm{ml}$} & $\begin{array}{c}\mathrm{I} \times \mathrm{I} \\
\mathrm{ml}\end{array}$ & $\begin{array}{c}\mathrm{I} X \\
0,1 \mathrm{ml}\end{array}$ \\
\hline A & + & + & + & + & + & + & + \\
\hline B & + & + & + & + & + & + & + \\
\hline C & + & + & + & + & + & + & + \\
\hline $\mathrm{D}$ & + & + & + & + & + & + & + \\
\hline$E$ & + & + & + & + & + & + & + \\
\hline $\mathrm{F}$ & + & + & + & + & + & + & + \\
\hline $\mathrm{G}$ & + & + & + & + & + & + & + \\
\hline $\mathrm{H}$ & + & + & + & + & + & + & + \\
\hline I & + & + & + & + & + & + & + \\
\hline $\mathrm{J}$ & + & + & + & + & + & + & + \\
\hline $\mathrm{K}$ & + & + & + & + & + & + & + \\
\hline $\mathrm{L}$ & + & + & + & + & + & + & + \\
\hline
\end{tabular}

Keterangan : A sampai J (Sampel susu kedelai murni tanpa merek, $\mathrm{K}$ \& L (Sampel susu kedelai murni dengan merek), + (hasil positif). 


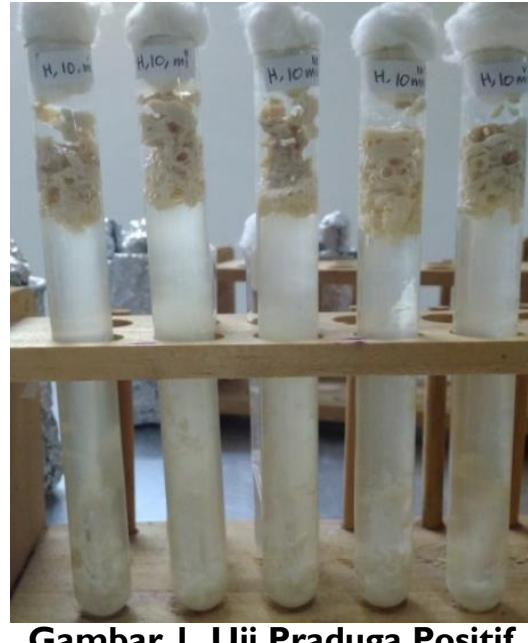

Gambar I. Uji Praduga Positif

Dari hasil uji praduga pada media Lactose Broth (LB) hasil yang positif (+) akan dilanjutkan ke uji penegasan pada media Brilliant Green Lactose Broth (BGLB).

\section{Uji Penegas (Confirmative Test)}

Hasil yang menujukkan positif $(+)$ uji penegas pada media Brillian Green Lactose bile broth (BGLBB) akan adannya gas atau gelembung didalam tabung durham dan di atas permukaan tabung reaksi, dan mengalami kekeruhan serta berubah warna hijau toska atau biru toska pada media Brillian Green Lactose broth (BGLB), jika hasil menujukkan negatif (-) uji penegas pada media Brillian Green Lactose broth (BGLB) tidak akan munculnya gas atau gelembung di dalam tabung durham dan permukaan tabung reaksi, dan tidak mengalami kekeruhan dan perubahan warna pada media Brillian Green Lactose broth (BGLB).

Pada tabel 2. menujukkan hasil uji penegas pada media Brillian Green Lactose broth (BGLB), sampel susu kedelai yang telah di inkubasi selama \pm 24 jam pada suhu $36^{\circ} \mathrm{C}$ di dalam incubator menujukkan bahwa sampel susu kedelai murni $A, B, E, G, H, I$, J, dan sampel susu kedelai bermerek $\mathrm{K}$ memiliki nilai index Most Probable Number $(M P N) \leq 979 / 100 \mathrm{ml}$ yang berarti mengandung s 979 bakteri coliform dalam $100 \mathrm{ml}$, sampel susu kedelai. Sampel susu kedelai $C$ memiliki nilai index Most Probable Number (MPN) 10/100 ml yang berarti mengandung 10 bakteri coliform dalam $100 \mathrm{ml}$, sampel susu kedelai. Sampel susu kedelai D memiliki nilai index Most Probable Number (MPN) 16/100 ml yang berarti mengandung 16 bakteri coliform dalam $100 \mathrm{ml}$, sampel susu kedelai. Sampel susu kedelai $F$ memiliki nilai index Most Probable Number (MPN) 84/100 ml yang berarti mengandung 84 bakteri coliform dalam 100 $\mathrm{ml}$, sampel susu kedelai, dan sampel susu kedelai $\mathrm{L}$ memiliki nilai index Most Probable Number (MPN) 265/100 ml yang berarti mengandung 265 bakteri coliform dalam $100 \mathrm{ml}$, sampel susu kedelai.

Tabel 2. Hasil Uji Penegas

\begin{tabular}{|c|c|c|c|c|}
\hline \multirow[b]{2}{*}{ Sampel } & \multicolumn{3}{|c|}{ Jumlah Tabung Positif (+) } & \multirow{2}{*}{$\begin{array}{l}\text { Index MPN Per } \\
\qquad 100 \mathrm{ml}\end{array}$} \\
\hline & $\begin{array}{c}5 \times 10 \\
\mathrm{ml}\end{array}$ & $\begin{array}{c}\mathrm{IXI} \\
\mathrm{ml}\end{array}$ & $\mathrm{I} \times 0, \mathrm{I} \mathrm{ml}$ & \\
\hline $\mathrm{A}$ & 5 & I & I & $\leq 979$ \\
\hline B & 5 & I & I & $\leq 979$ \\
\hline $\mathrm{C}$ & 2 & $\mathrm{I}$ & $\mathrm{I}$ & 10 \\
\hline $\mathrm{D}$ & 3 & $\mathrm{I}$ & $\mathrm{I}$ & 16 \\
\hline $\mathrm{E}$ & 5 & $\mathrm{I}$ & $\mathrm{I}$ & $\leq 979$ \\
\hline $\mathrm{F}$ & 5 & 0 & I & 84 \\
\hline $\mathrm{G}$ & 5 & $\mathrm{I}$ & $\mathrm{I}$ & $\leq 979$ \\
\hline $\mathrm{H}$ & 5 & $\mathrm{I}$ & $\mathrm{I}$ & $\leq 979$ \\
\hline $\mathrm{I}$ & 5 & $\mathrm{I}$ & $\mathrm{I}$ & $\leq 979$ \\
\hline $\mathrm{J}$ & 5 & I & I & $\leq 979$ \\
\hline K & 5 & I & I & $\leq 979$ \\
\hline $\mathrm{L}$ & 5 & I & 0 & 265 \\
\hline
\end{tabular}

Keterangan : A sampai J (Sampel susu kedelai murni tanpa merek, K \& L (Sampel susu kedelai murni dengan merek).

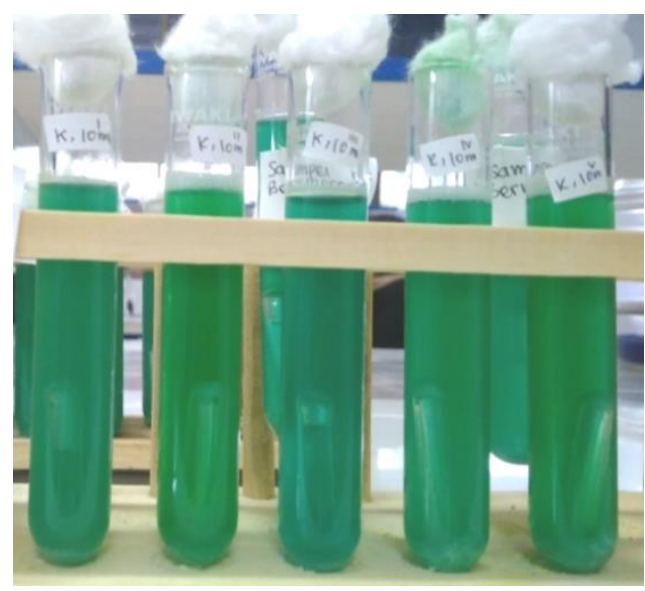

Gambar 2. Uji Penegas Positif

\section{Uji pelengkap (Completed Test)}

Hasil uji pelengkap (Completed Test) pada media Eosin Methylene Blue Agar (EMBA), sampel susu kedelai yang telah di inkubasi selama \pm 24 jam pada suhu $36^{\circ} \mathrm{C}$ didalam inkubator diketahui bahwa dari 12 sampel susu kedelai ditemukan 6 sampel susu kedelai menujukkan hasi positif (+) mengandung bakteri Escherichia coli, jika sampel susu kedelai mengandung bakteri Escherichia 
Sri Hainal, Trie Yuni Elfasyari, Rofina Intan Sulistya. 2021. Identifikation Of Escherichia Coli In Pure Soy Milk At The Market Of Jodoh Batam City

coli maka pada media Eosin Methylene Blue Agar (EMBA) akan berubah warna menjadi hijau metalik di cawan petri sesuai bentuk yang kita koreskan. Sedangkan 5 sampel susu kedelai yang lainnya menujukkan hasil negatif (-) membentuk koloni atau tidak bewarna.

Tabel 3. Hasil Uji Pelengkap

\begin{tabular}{|c|c|c|c|c|c|c|c|}
\hline \multirow{3}{*}{$\begin{array}{l}\mathrm{S} \\
\mathrm{A} \\
\mathrm{M} \\
\mathrm{P} \\
\mathrm{E} \\
\mathrm{L}\end{array}$} & \multicolumn{7}{|c|}{ Hasil Uji Pelengkap pada Media Lactose Broth (LB) } \\
\hline & Seri I & Seri II & Seri III & $\begin{array}{c}\text { Seri } \\
\text { IV }\end{array}$ & $\begin{array}{c}\text { Seri } \\
V\end{array}$ & Seri & Seri \\
\hline & \multicolumn{5}{|c|}{$5 \times 10 \mathrm{ml}$} & $\begin{array}{c}I X I \\
M L\end{array}$ & $\begin{array}{l}I X \\
0, I \\
M L\end{array}$ \\
\hline A & + & + & - & - & - & - & - \\
\hline B & + & + & + & - & - & - & - \\
\hline $\mathrm{C}$ & + & - & - & - & - & - & + \\
\hline $\mathrm{D}$ & + & - & + & - & - & - & + \\
\hline $\mathrm{E}$ & - & - & - & - & - & - & - \\
\hline $\mathrm{F}$ & - & - & - & - & - & - & - \\
\hline $\mathrm{G}$ & - & - & + & - & - & + & + \\
\hline $\mathrm{H}$ & - & - & - & - & - & - & - \\
\hline $\mathrm{I}$ & - & - & - & - & - & - & - \\
\hline $\mathrm{J}$ & - & - & - & - & - & - & - \\
\hline $\mathrm{K}$ & - & - & - & - & + & - & - \\
\hline $\mathrm{L}$ & - & - & - & - & - & - & - \\
\hline
\end{tabular}

Keterangan : A sampai J (Sampel susu kedelai murni tanpa merek, K \& L (Sampel susu kedelai murni dengan merek), + (hasil positif) dan - (Hasil Negatif).

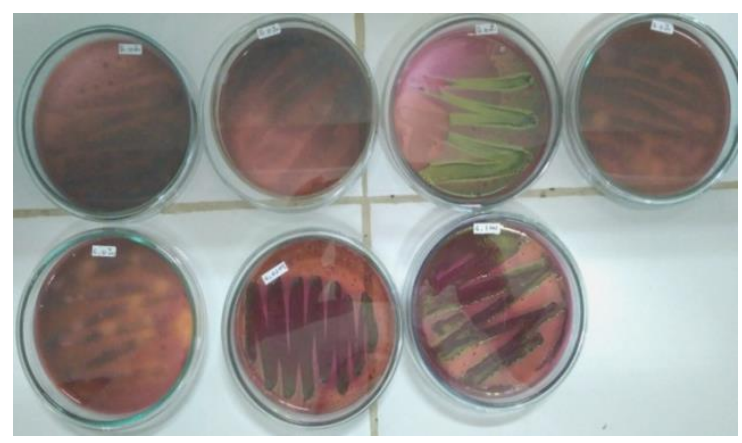

Gambar 3. Hasil Uji Pelengkap yang Positif

Berdasarkan hasil penelitian sebelumnya oleh (Alfiyah et al., 2018), 13 sampel susu kedelai yang dijual di toko-toko di Desa Sumobito Jombang diperoleh 8 sampel positif $(+)$ terkontaminasi Escherichia coli dan 5 sampel negatif.

Penelitian (Manto \& Hilal, 2016) dan (Hutagaol, 2017) mengenai 8 sampel minuman susu kedelai yang dijual di pasar Kliwon Karang Lewas, diketahui dari 8 sampel susu kedelai ditemukan 4 sampel positif (+) mengandung Escherichia coli. bakteri dan 4 sampel lainnya menunjukkan hasil negatif (-) atau tidak mengandung bakteri Escherichia coli.
Penelitian minuman susu kedelai pada usaha kecil di kota Medan. Bahwa dari 10 sampel susu kedelai, 6 sampel sudah memenuhi syarat kesehatan setelah dibandingkan dengan SK Menteri Kesehatan Nomor 907 / MENKES / SK / VII / 2002 yaitu 0 dalam 100 ml sampel sedangkan 4 sampel lagi mengandung Escherichia coli dalam $100 \mathrm{ml}$ (Sinaga, 2017).

Berdasarkan persyaratan Standar Nasional Indonesia (SNI 0 I - 3830 - 1995) sampel susu kedelai yang diuji tidak memenuhi persyaratan, hasil nilai indeks yang diperoleh dari sampel susu kedelai melebihi ambang batas jika mengacu pada standar yang telah ditetapkan, sampel susu kedelai tidak layak dikonsumsi. Hal ini dapat terjadi karena lingkungan atau tempat pembuatannya tidak higienis dan sanitasi yang kurang terjaga, sehingga makanan dan minuman dapat terkontaminasi oleh mikroorganisme.

\section{KESIMPULAN}

Berdasarkan penelitian yang telah dilaksanakan dengan judul "Identifikasi Bakteri Escherichia coliPada Susu Kedelai Murni Di Pasar Jodoh Kota Batam Dengan Metode Most Probable Number (MPN)" dapat di ambil kesimpulan sebagai berikut :

I. Hasil penelitian pada 10 sampel susu kedelai murni A, B, C, D, E, F, G, H, I, J dan 2 sampel susu kedelai bermerek $K$, dan $L$ terdapat bakteri coliformdan terdapat 6 bakteri Escherichia coli pada sampel susu kedelai murni A, B, C, D, G, dan pada sampel susu kedelai bermerek $\mathrm{K}$.

2. Dari hasil pemeriksaan 12 sampel susu kedelai tidak memenuhi syarat Standar Nasional Indonesia (SNI 01 - 3830 - 1995), karena nilai index 12 sampel susu kedelai melebihi ambang batas, jika merujuk pada standar yang telah ditetapkan, maka sampel susu kedelai tersebut tidak layak untuk dikonsumsi.

\section{UCAPAN TERIMA KASIH}


Terimakasih dan bersyukur atas dukungan semua pihak Institut Kesehatan Mitra Bunda yang telah menyediakan fasilitas penelitian.

\section{REFERENSI}

I. Habullah, R., \& Kojong, N. (20I5). Analysis of Coliform Bacteria Contamination and Escherichia coli soy milk sold in Supermarkets of Manado city. Pharmacon, 4(I), 20-3I. https://doi.org// 0.35799/pha.4.2015.6477

2. Sunarti, R. N. (20I7). Uji Kualitas Air Sumur Dengan Menggunakan Metode MPN (Most Probable Numbers).

3. Sinaga, E. M. (20I7). Identifikasi Bakteri Escherichia coli Pada Es Kristal Dengan Menggunakan Metode Most Probable Number (MPN) yang Diperjualbelikan Oleh Pedagang di Jalan Kapten Muslim Medan Tahun 2017. Jurnal Mutiara Kesehatan Masyarakat, 10(7), 4I-47.

4. Alfiyah, N., Maududi, A., \& Lestari, S. (20/8). IDENTIFIKASI BAKTERI Escherichia coli PADA SUSU KEDELAI YANG DIJUAL DI TOKOTOKO DESA SUMOBITO JOMBANG. Jurnal Insan Cendekia, 4(2), 58-63. https://doi.org//0.35874/jic.v4i2.316

5. Sanjaya, T. A., \& Apriliana, E. (20/3). Deteksi Escherichia coli Pada Jajanan Cendol Yang Dijual Di Pasar Tradisional Detection Of Escherichia coli In Snack Cendol That Sold At Traditional Market In Bandar Lampung City Pendahuluan Escherichia coli adalah bakteri yang merupakan bagian dari mikro. MAJORITY (Medical Journal of Lampung University), 10-17. http://juke.kedokteran.unila.ac.id/index.php/majori ty/article/viewFile/35/34

6. Elfidasari, D. (20II). Perbandingan Kualitas Es di Lingkungan Universitas Al Azhar Indonesia dengan Restoran Fast Food di Daerah Senayan dengan Indikator Jumlah Escherichia coli Terlarut. JURNAL Al-AZHAR INDONESIA SERI SAINS DAN TEKNOLOGI, I(I), 18. https://doi.org/l0.36722/sst.vlil.I4

7. Manto, S. I., \& Hilal, N. (2016). Susu Kedelai Di Pasar Kliwon Karang Lewas Tahun 2016.
8. Hutagaol, I. F. (20I7). Identifikasi Bakteri pada Tangan Penjual Makanan di Kawasan SD di Kelurahan Tanjung Rejo.

9. Jiwintarum, Y., Agrijanti, \& Septiana, B. L. (2017). Most Probable Number (Mpn) Coliform Dengan Variasi Volume Media Lactose Broth Single Strength (Lbss) Dan Lactose Broth Double Strength (Lbds). Jurnal Kesehatan Prima, I I (I), I. 